\title{
Distortions Resulting from Residential Land Use Controls in Metropolitan Areas
}

\author{
Brian N. Jansen • Edwin S. Mills
}

Published online: 12 April 2011

C The Author(s) 2011. This article is published with open access at Springerlink.com

\begin{abstract}
Residential land use controls in metropolitan areas are intended to and typically do restrict housing supply and inevitably raise housing prices. This paper estimates the effects of metropolitan area land use controls on housing prices, employing a remarkable data set compiled by Gyourko, Saiz and Summers. We embed the estimates in a four equation model that estimates the effects of the resulting high housing prices on metropolitan population, real incomes and employment.
\end{abstract}

Keywords Density controls $\cdot$ Housing prices $\cdot$ Real incomes $\cdot$ Population · Employment $\cdot$ Residential land use controls $\cdot$ Stringent restrictions $\cdot$ Metropolitan statistical areas $\cdot$ Panel data $\cdot$ Land index $\cdot$ Logged variables $\cdot$ Spatial equilibrium distribution

\section{Introduction}

Residential land use controls are mostly intended to and do limit housing densities. Restrictions to single family detached houses, minimum lot sizes, height limitations, floor/area ratio limits and restrictions on numbers of buildings per lot are examples. See Mills (2007) for a rogue's gallery of controls. Such restrictions artificially limit housing supply and inevitably raise housing prices. It has been documented that land use

Financial support was provided by the Kellogg School of Management. We are indebted to Craig Furfine, Ravi Jagannathan and referees for this journal for comments on an earlier draft.

\footnotetext{
B. N. Jansen

Bain and Company, Boston, MA, USA

e-mail: brian.northrop.jansen@gmail.com

E. S. Mills $(\bowtie)$

Kellogg School of Management, Evanston, IL, USA

e-mail: e-mills@kellogg.northwestern.edu
} 
controls raise house prices in at least some metropolitan statistical areas (MSAs) that are extreme cases of controls, especially Boston, New York and large California MSAs. See Hamilton (1975), Ellickson (1997), Glaeser et al. (2005), and Ihlanfeldt (2007). If controls raise house prices, they presumably affect other MSA characteristics, although such effects have not been documented.

This paper analyzes the above issues making use of a remarkable and comprehensive data set for which the profession is indebted to Gyourko et al. (2008) (GSS). GSS collected many measures of land use controls and calculated a summary index for a large number of local government jurisdictions and for MSAs in the US. The GSS MSA index of land use control stringency is carefully composed from 11 sub-indexes and is by far the best index of the stringency of land use controls available. Their measures pertain to 2006. Their MSA land use control stringency data are summarized in an index L, normalized to $-2 \leq \mathrm{L} \leq 4$. See GSS for a detailed description of their data and index.

An alternative and correlated index of a determinant of MSA housing prices is the Saiz (2010) index of restrictions on building from geographic interferences, specifically slopes in excess of $15^{\circ}$. See Glaeser et al. (2008). Steep slopes obviously make construction difficult or impossible. In some cases, including Denver and Los Angeles, steep slopes in one direction simply induce development in other directions. But such slopes may nevertheless cause higher housing prices. Why the presence of steep slopes should be correlated with stringent land use controls is a mystery. We presume that steep slopes would be correlated with less stringent controls on buildable land if residents' welfare were the goal of such controls.

Many papers during recent years have studied the endogeneity of local land use controls. See Fischel (1985), Quigley and Raphael (2005) and Wallace (1988) for fine examples. Of course, everything governments do is determined by actions of elected and appointed officials and by lobbyists. All are influenced by market conditions. Appointed zoning boards stand between elected officials and private parties. Whether that makes zoning decisions more nearly exogenous than other government actions is an open question.

Some papers claim that causation may be the reverse of that assumed here, namely that stringent land use controls attract high income residents. See Nelson (1999), Carruthers and Gudmunder (2007) and references therein. That is undoubtedly correct at the neighborhood level, in which case higher house prices in one neighborhood are associated with lower house prices in nearby lower income neighborhoods. However, it is difficult to believe that stringent land use controls have significant effect in attracting high income residents to an MSA as a whole. If that was the case, our estimates would indicate that stringent controls were associated with high income residents, but our estimates show the reverse effect.

We supplement these data with conventional data on population, employment, income and housing prices, all by MSA. Our data set includes observations for 268 MSAs.

We estimate a conventional four simultaneous equation model in which MSA population, employment, per capita real income and real housing prices are the dependent variables. The basic hypothesis is that land use controls increase housing prices and the other three equations indicate how housing prices affect the other three endogenous variables. The model is an expansion and update of that in Mills and Lubuele (1995). 
We estimate the model for 2006, using 2001 values for the lagged dependent variables. The land use control index is for 2006. That is the appropriate year for our data set. Land use controls are assumed to be exogenous. Such controls are instruments of local governments in the US. It has been well documented that such controls have become increasingly and sometimes erratically more stringent during the 20th century (See Fischel 2004; Glaeser et al. 2005; Glaeser and Ward 2009; Schwieterman and Caspell 2006; Mills 2007). Scholars typically assume that exogeneity is a tolerable approximation for such actions. It is probably a better approximation for land use controls than for many other actions of local governments.

Each of the four simultaneous equations contains its lagged dependent variable and its square, the other three endogenous variables and 10 census regional dummies, to capture amenities and other factors that vary regionally. The housing price equation also includes the land use control index, allowing land use controls to affect housing prices directly and the other three endogenous variables via the effects of housing prices on them.

Our model is less ambitious than the pathbreaking work of Glaeser and Gottlieb (2009). They present and estimate a spatial equilibrium distribution of MSA sizes in the US. We simply take MSA characteristics as they were in 2006 and ask how their characteristics were affected by land use controls.

\section{The Model}

Our model is not derived from basic theories of producer and consumer behavior. Nor are other models of urban growth. Glaeser and Gottlieb (2009) show that MSA growth is correlated with educational attainment of residents, an important finding. But neither we nor other writers have a model of the basic behavioral determinants of MSA growth. Such a model would need to include reasons for regional growth, such as the move to the sunbelt, and many other determinants such as the overall urbanization of the country. We must leave that ambitious endeavor to other writers.

Our model is an expansion and updating of that in Mills and Sende Lubuele (1995). The 1995 model was used to forecast MSSA growth to 2000 and informal calculations by the senior author suggest that the forecasts are as accurate as other publicly available forecasts.

In our model, the inclusion of lagged dependent variables and regional dummies is intended to capture effects of basic determinants of MSA size that change slowly or not at all through time.

The expanded model is

$$
\begin{aligned}
& \mathrm{P}_{\text {it }}=\mathrm{a}_{0}+\mathrm{a}_{1} \mathrm{~W}_{\mathrm{it}}+\mathrm{a}_{2} \mathrm{E}_{\mathrm{it}}+\mathrm{a}_{3} \mathrm{H}_{\mathrm{it}}+\mathrm{a}_{4} \mathrm{P}_{\mathrm{it}-1}+\mathrm{a}_{5} \mathrm{P}_{\mathrm{it}-1}^{2}+\mathrm{a}_{6} \mathrm{r}_{\mathrm{ij}} \\
& \mathrm{W}_{\mathrm{it}}=\mathrm{b}_{0}+\mathrm{b}_{1} \mathrm{P}_{\mathrm{it}}+\mathrm{b}_{2} \mathrm{E}_{\mathrm{it}}+\mathrm{b}_{3} \mathrm{H}_{\mathrm{it}}+\mathrm{b}_{4} \mathrm{~W}_{\mathrm{it}-1}+\mathrm{b}_{5} \mathrm{~W}^{2}{ }_{\mathrm{it}-1}+\mathrm{b}_{6} \mathrm{r}_{\mathrm{ij}} \\
& \mathrm{E}_{\mathrm{it}}=\mathrm{c}_{0}+\mathrm{c}_{1} \mathrm{P}_{\mathrm{it}}+\mathrm{c}_{2} \mathrm{~W}_{\mathrm{it}+} \mathrm{c}_{3} \mathrm{H}_{\mathrm{it}+} \mathrm{c}_{4} \mathrm{E}_{\mathrm{it}-1}+\mathrm{c}_{5} \mathrm{E}_{\mathrm{it}-1}^{2}+\mathrm{c}_{6} \mathrm{r}_{\mathrm{ij}} \\
& \mathrm{H}_{\mathrm{it}}=\mathrm{d}_{0}+\mathrm{d}_{1} \mathrm{P}_{\mathrm{it}}+\mathrm{d}_{2} \mathrm{~W}_{\mathrm{it}}+\mathrm{d}_{3} \mathrm{E}_{\mathrm{it}}+\mathrm{d}_{4} \mathrm{H}_{\mathrm{it}-1}+\mathrm{d}_{5} \mathrm{H}_{\mathrm{it}-1}^{2}+\mathrm{d}_{6} \mathrm{r}_{\mathrm{ij}}+\mathrm{d}_{7} \mathrm{~L}_{\mathrm{i}}
\end{aligned}
$$

Here it subscripts indicate the ith MSA in year $\mathrm{t}, \mathrm{P}_{\mathrm{it}}=$ population, $\mathrm{W}_{\mathrm{it}}=$ real income per capita, $\mathrm{E}_{\mathrm{it}}=$ total employment, $\mathrm{H}_{\mathrm{it}}=$ real housing price, $\mathrm{r}_{\mathrm{ij}}$ takes the value 
one if the ith MSA is in the jth of the 10 census regions and zero otherwise, and $\mathrm{L}_{\mathrm{i}}$ is the GSS index of land use control stringency in the ith MSA in 2006.

The four equations were estimated for $t=2006$, the year for which the land use control index is reported, and $t-1=2001$. The 5 year lag and its square for the dependent variables are arbitrary, and are intended to allow for MSA characteristics that differ among MSAs but change slowly through time. Reported estimates are linear. Log versions were also estimated, but are not reported (Logs cannot be taken for regional dummies or for the land use control index). All estimates were computed by three-stage least squares. Estimates are for the $268 \mathrm{MSAs}$ for which complete data are available.

\section{Structural Equation Estimates ${ }^{1}$}

Table 1 displays the estimated equations. The $R^{2} \mathrm{~s}$ are extremely high, but each equation contains the lagged dependent variable (and its square) as a right hand variable. Readers will not be surprised that these dependent variables are highly correlated with their values 5 years earlier.

Coefficient signs are mostly as should be expected. Dependent variables are of course positively and strongly correlated with their lagged values. Squared lagged dependent variables have negative effects on all four dependent variables, indicating decelerating effects of high lagged dependent variable values.

Stringent land use controls raised house values, and high house prices depressed population, real incomes and employment. These results should be expected at the time of extremely high house prices in 2006, the year before their peak. Regional dummies have mixed signs and magnitudes. Regional dummy locations are given in Appendix I. Regional effects generally accord with intuitive views. New York and California (regions 5 and 7) have high house prices, whereas the Midwest and great plains (regions 4 and 6) have low house prices. Region 7, dominated by California, has the largest regional effect on house prices.

The estimates in Table 1 strongly confirm the hypothesis of this paper: stringent land use controls raise house prices, and high house prices lower population, real incomes and employment. The coefficient estimate of $\mathrm{L}$ in the housing price equation is highly significant.

\section{Reduced from Calculations}

Table 1 shows structural model estimates, permitting each dependent variable to affect the other three. But primary interest should be in the reduced form equations in which interactive effects are solved out.

Table 2 presents the reduced form equations calculated from the structural equations in Table 1 . Table 2 presents reduced form calculations conditional on the

\footnotetext{
${ }^{1}$ All the data employed to estimate the four equations can be found at www.duke.edu/ bnj. Brief descriptions of the data are in Appendix II.
} 
Table 1 Structural equations

\begin{tabular}{|c|c|c|c|c|c|c|c|c|}
\hline Dependent variable & $P_{t}$ & $\begin{array}{l}\text { Standard } \\
\text { errors }\end{array}$ & $\mathrm{W}_{\mathrm{t}}$ & $\begin{array}{l}\text { Standard } \\
\text { errors }\end{array}$ & $\mathrm{E}_{\mathrm{t}}$ & $\begin{array}{l}\text { Standard } \\
\text { errors }\end{array}$ & $\mathrm{H}_{\mathrm{t}}$ & $\begin{array}{l}\text { Standard } \\
\text { errors }\end{array}$ \\
\hline Intercept & 65.3 & 45.5 & -1688 & 1298 & 34.6 & 22.8 & 286 & 90.7 \\
\hline$P_{t}$ & - & - & 1.40 & .697 & $.976 \mathrm{e}^{-1}$ & $.49 \mathrm{e}^{-1}$ & $.510 \mathrm{e}^{-1}$ &, $134 \mathrm{e}^{-{ }^{1}}$ \\
\hline $\mathrm{W}_{\mathrm{t}}$ & $.78 \mathrm{e}^{-{ }^{4}}$ & $100 \mathrm{e}^{-{ }^{2}}$ & - & - & $.207 \mathrm{e}^{-3}$ & $.503 \mathrm{e}^{-{ }^{3}}$ & $.109 \mathrm{e}^{-{ }^{2}}$ & $373 e^{-3}$ \\
\hline $\mathrm{E}_{\mathrm{t}}$ & -.263 & $.600 \mathrm{e}^{-1}$ & -2.43 & 1.18 & - & - & $.844 \mathrm{e}^{-1}$ & $.227 \mathrm{e}^{-1}$ \\
\hline $\mathrm{H}_{\mathrm{t}}$ & -.210 & .224 & -4.89 & 4.23 & -.144 & .108 & - & - \\
\hline $\begin{array}{l}\text { Lagged Dependent } \\
\text { Variable }\end{array}$ & 1.26 & $.408 \mathrm{e}^{-1}$ & 1.15 & $.670 \mathrm{e}^{-1}$ & -908 & $.258 \mathrm{e}^{-1}$ & 45.155 & 1.24 \\
\hline $\begin{array}{l}\text { Lagged Dependent } \\
\text { Variable Squared }\end{array}$ & -4.88 & $5.11 \mathrm{e}^{-7}$ & $-2.98 \mathrm{e}^{-7}$ & $8.50 \mathrm{e}^{-7}$ & $-3.75 e^{-6}$ & $6.78 \mathrm{e}^{-7}$ & $-.133 \mathrm{e}^{-1}$ & $.424 \mathrm{e}^{-2}$ \\
\hline $\mathrm{L}$ & - & - & - & - & - & - & 12.4 & 2.44 \\
\hline$r_{1}$ & -73.9 & 33.0 & 28.3 & 6.5 & 19.7 & 16.1 & 2.56 & 12.7 \\
\hline$r_{2}$ & -54.9 & 26.8 & 647 & 496 & 9.03 & 13.1 & 5.96 & 10.2 \\
\hline$r_{3}$ & -11.7 & 26.4 & 1192 & 493 & .632 & 13.0 & 10.3 & 10.1 \\
\hline$r_{4}$ & -72.7 & 26.1 & -478 & 480 & -31.8 & 12.6 & -29.3 & 9.69 \\
\hline$r_{5}$ & -79.5 & 81.8 & 771 & 5.98 & -22.5 & 15.4 & 13.2 & 12.3 \\
\hline$r_{6}$ & -40.5 & 29.7 & 279 & 552 & -16.8 & 14.5 & -17.2 & 11.4 \\
\hline$r_{7}$ & -11.7 & 35.2 & 1337 & 666 & -7.27 & 17.8 & 68.4 & 11.6 \\
\hline$r_{9}$ & -166 & 34.6 & 137 & 647 & -1.94 & 17.0 & 12.4 & 132 \\
\hline $\mathrm{r}_{9}$ & -33.6 & 30.1 & 1498 & 554 & -17.6 & 14.7 & -17.4 & 113 \\
\hline$r_{10}$ & -20.2 & 29.2 & 372 & 544 & -6.35 & 14.3 & -11.3 & 11.2 \\
\hline$R^{2}$ & .998 & & .955 & & .999 & & .713 & \\
\hline
\end{tabular}

$t=2006, t-1=2001$

exogenous variables ( $\mathrm{L}$ and the regional dummies) and the predetermined variables (the lagged endogenous variables and their squares).

Coefficients of the land use control index have the same signs in the reduced form equation estimates as in the structural equation estimates. Thus, after solving out the interaction effects among the dependent variables, our estimates indicate that stringent land use controls raise house prices and lower population, real incomes and employment in MSAs.

The estimates in Tables 1 and 2 provide strong evidence that land use controls are deleterious at the MSA level. Land use controls are set at local, not MSA, levels, although they are strongly correlated within an MSA. The fact that controls are harmful at the MSA level does not imply that no one benefits from them. Individual households who lobby and vote for controls may benefit, or at least believe that they benefit, and it is possible that entire autonomous communities within an MSA may benefit.

A simple calculation reveals the practical magnitude of the effects of the land use control index. By our estimates, a standard deviation reduction in the land use control index would cause the mean house price in 2006 to have been $5.15 \%$ lower. If the land use control index were $20 \%$ lower than its minimum value, the mean house price would have been $2.10 \%$ lower. 
Table 2 Reduced form equations

\begin{tabular}{|c|c|c|c|c|}
\hline Dependent variable & $P_{t}$ & $\mathrm{~W}_{\mathrm{t}}$ & $\mathrm{E}_{\mathrm{t}}$ & $\mathrm{H}_{\mathrm{t}}$ \\
\hline Intercept & 103.23 & -343.22 & 85.97 & -288.3 \\
\hline$P_{t-1}$ & 1.220 & 1.173 & .111 & $.541^{\mathrm{e}^{-1}}$ \\
\hline $\mathrm{P}_{\mathrm{t}-1}^{2}$ & $-4.72^{\mathrm{e}-6}$ & $.454^{\mathrm{e}^{-7}}$ & $-4.32^{\mathrm{e}-7}$ & $-.209^{\mathrm{e}-8}$ \\
\hline $\mathrm{W}_{\mathrm{t}-1}$ & $-.180^{\mathrm{e}-3}$ & 1.141 & $.429^{\mathrm{e}-4}$ & $.122^{\mathrm{e}-2}$ \\
\hline $\mathrm{W}_{\mathrm{t}-1}^{2}$ & $4.67^{\mathrm{e}-11}$ & $-2.96^{\mathrm{e}-7}$ & $-1.11^{\mathrm{e}-11}$ & $.319^{\mathrm{e}-9}$ \\
\hline $\mathrm{E}_{\mathrm{t}-1}$ & .218 & -2.054 & .900 & $.892^{\mathrm{e}^{-1}}$ \\
\hline$E_{t-1}^{2}$ & $9.00^{\mathrm{e}-7}$ & $8.49^{\mathrm{e}-6}$ & $3.713^{\mathrm{e}-6}$ & $.369^{\mathrm{e}-8}$ \\
\hline $\mathrm{H}_{\mathrm{t}-1}$ & .866 & -24.41 & .830 & 5.15 \\
\hline $\mathrm{H}_{\mathrm{t}-1}^{2}$ & $.224^{\mathrm{e}-2}$ & $.631^{\mathrm{e}^{-1}}$ & $.215^{\mathrm{e}-2}$ & $-.133^{\mathrm{e}^{-1}}$ \\
\hline $\mathrm{L}$ & -2.078 & -58.54 & -1.991 & 12.37 \\
\hline$r_{1}$ & -67.24 & -8.19 & -26.42 & 1.348 \\
\hline$r_{2}$ & -52.06 & 584.7 & -14.73 & 5.185 \\
\hline$r_{3}$ & -13.07 & 1127.0 & -3.27 & 11.100 \\
\hline$r_{4}$ & -57.68 & -332.4 & -33.18 & -29.83 \\
\hline$r_{5}$ & -73.86 & 681.4 & 31.44 & 12.81 \\
\hline$r_{6}$ & -32.32 & 359.1 & -17.48 & -17.0 \\
\hline$r_{7}$ & -67.24 & 1011.4 & -19.2 & 70.05 \\
\hline $\mathrm{r}_{9}$ & -17.74 & 66.74 & -5.39 & 12.07 \\
\hline$r_{9}$ & -25.6 & 1580.6 & -17.5 & 15.46 \\
\hline$r_{10}$ & -16.8 & 418.8 & -6.30 & -11.16 \\
\hline
\end{tabular}

$t=2006, t-1=2001$

Panel Data Analysis

We also experimented with panel data.

Panel data analysis allows us to assume that each MSA has an unexplained quality that is constant over time. Then by investigating factors that do change over time we may be able to shed light on the properties of the variables we are interested in. A Hausman specification test comparing the estimated coefficients of a fixed effects regression and a random effects regression indicated that using a random effects model would yield inconsistent estimates.

Because the fixed-effects regressions difference away time-constant variables, the Land Index and regional dummy variables cannot be included on their own. Our panel data set includes an interaction variable between the dummy year variable and $\mathrm{L}$. The interaction variable measures the difference in impact of $\mathrm{L}$ on housing prices compared to the base year 2001. Thus, the coefficient is the percentage difference $(100 \times$ coefficient) in the effect on housing prices of moving from an index value of zero to one between the base year and 2006. The panel data set also includes yearly dummy variables that capture trends in housing prices that are not explained by the other independent variables. This makes the yearly dummy variables difficult to interpret as other variables contain significant trends over the sampled time period. 


\section{Analysis with Logged Variables}

When analyzing the simultaneous equation estimates, the effects of employment and population on housing prices were unclear. In the panel regression, the coefficients on income, population, and employment are all positive and significant in determining housing prices. Although not included in the results, a fixed-effects regression where housing price, population, employment and income are linear variables yields qualitatively similar results.

Analysis of the Land Index interaction variable yields interesting results. For the years 1997 through 2000, the impact of the 2006 Land Index is not significantly different from the base year 1996. However, beginning in 2001, L positively contributes to housing prices. This pattern continues through the sample period, with the importance of $\mathrm{L}$ in determining home prices increasing year over year from 2001 through 2006. In 2006, a high $2006 L$ value had a more significant upward impact on housing prices than in any previous year in the sample. This influence diminishes in 2007 and 2008, but remains positive and significant. Over the sample period, the impact that zoning regulations had on housing prices increased significantly and contributed to the rise in prices that characterized the period.

\section{Analysis with Housing Price Growth Rates}

The dependent variable in this fixed-effects regression is the yearly growth rate of housing prices, defined as the difference in log prices. In this regression, the dependent variables are linear, but an analysis of logged variables yields similar results. Again, the coefficient on income is positive and significant while employment and population have insignificant effects on housing price growth rates.

In this regression, the conclusions drawn about the regulatory landscape of real estate are similar to the previous ones. It is apparent that from 1999 until $2006 \mathrm{~L}$ positively influenced housing price growth rates to a higher degree than in 1996. Further, a high $L$ value in 2006 meant that an MSA had a higher likelihood of negative home price growth than in 1996. (In other words, having a high $L$ value in 2006 contributed more to the downward movement in 2007 and 2008 than it did in 1996). Thus, land use restrictions and zoning taxes played an increasing role in determining housing price changes during both times of positive and negative growth.

Another regression was estimated where the dependent variable was the absolute value of the housing price growth rate. This statistic can be interpreted as the volatility of home prices. The results are similar to the growth rate analysis because the sample time period was overwhelmingly a period of positive annual growth. When compared to $1996, L$ values were significantly more influential in creating home price volatility during the years from 1998 through 2005. This effect diminished in 2006 and 2007, but increased dramatically in 2008, the year of large declines in home prices among MSAs. From the start of the sample period, L increasingly contributed to the volatility and resulting instability of home prices. 
Results of the panel analysis are not presented in detail because the $\mathrm{L}$ index is not available for years other than 2006 that are analyzed in the panel analysis.

\section{A Conjecture}

Mills (2009) has conjectured that stringent land use controls promote not only high but also unstable house prices. If land use controls consistently promote rising house prices, then home owners are rationally highly leveraged regarding their dwellings. If house prices rise $15 \%$ per year, as they did during about 15 years in California MSAs ending in 2007, then households can easily afford dwellings worth 5 times their conventionally measured incomes. The $15 \%$ annual capital gain increases their measured incomes by $75 \%$ and is virtually tax free. The household can rationally not only afford a dwelling whose value is many times its measured income, but also it can rationally leverage its equity with the largest mortgage for which it can qualify. That maximizes the return on its equity in the dwelling. Mortgage lenders could rationally provide large mortgages relative to dwelling values because the mortgage declined $15 \%$ per year relative to the dwelling's value, even in the absence of equity payments on the mortgage, so defaults were rare. Lenders and organizations in the secondary mortgage market were also highly leveraged for the same reason.

The only requirement to make this scenario rational is the expectation that rapid house price inflation will continue a few more years. But the bonanza cannot continue indefinitely. The resulting high labor and other costs make it increasingly difficult for local producers to sell their products and services elsewhere. Alternatively, interest rates may rise. Or housing supply may eventually catch up to demand as developers build dwellings in distant but less stringently regulated suburban areas.

Preliminary confirmation of the conjecture that stringent controls contributed to house price instability is that the correlation between the land use regulation index and MSA house price changes (decreases) from 2007 to 2008 is -.368 .

\section{Conclusions}

Our estimates of our simple four simultaneous equation model imply that, at least in 2006, stringent density controls in an MSA raised housing prices and lowered real incomes, employment and population.

The strong conclusion of this paper is that stringent residential land use controls were a primary cause of the massive house price inflation from about 1992 to 2006 and possibly of the deflation that started in 2007.

Indeed, it is difficult to imagine another plausible cause of the 2008-2009 financial crisis. Popular accounts simply refer to a speculative housing price bubble. But productivity growth in housing construction is faster than in the economy as a whole (see Mills 2009) and the US has an aggressive and competitive housing construction sector. In the absence of excessive controls, housing construction would quickly deflate a speculative housing price bubble.

A final comment is that there appears to be no interest at any level of government, or among the articulate population, in reducing the stringency of land use controls. Indeed, recent trends are in the opposite direction. 
Open Access This article is distributed under the terms of the Creative Commons Attribution Noncommercial License which permits any noncommercial use, distribution, and reproduction in any medium, provided the original author(s) and source are credited.

\section{Appendix I}

\section{Region Variables}

Regions are defined by the Office of Management and Budget.

Region 1: New England: Maine, Massachusetts, New Hampshire, Vermont, Connecticut, Rhode Island

Region 2: Mid-Atlantic: Delaware, Virginia, District of Columbia, West Virginia, Maryland, Pennsylvania

Region 3: South-East: South Carolina, North Carolina, Georgia, Florida, Alabama, Mississippi, Tennessee, Kentucky

Region 4: Mid-West: Ohio, Indiana, Illinois, Michigan, Wisconsin, Minnesota

Region 5: New York, New Jersey

Region 6: Great Plains: Nebraska, Missouri, Iowa, Kansas

Region 7: South-West: Arizona, Nevada, California, Hawaii

Region 8: Pacific NW: Alaska, Oregon, Washington, Idaho

Region 9: South: Texas, Arkansas, Louisiana, Oklahoma

Region 10: Mountain: Colorado, Utah, Wyoming, Montana, North Dakota, South Dakota, New Mexico

\section{Appendix II}

\section{Description of Data Set}

The data set used in this paper contains a total of 268 MSAs as defined by the Office of Management and Budget, December 2005. In cases where a large MSA was also classified as containing a Metropolitan Division (MDIV), the MSA was broken down into areas according to its MDIV classification to create a more descriptive data set. For example, the Chicago MSA was divided into 3 areas: Chicago, IL; Gary, IN; and Lake County-Kenosha, WI. To avoid imputing missing housing price data, the data set starts in 1996 and continues through 2008, for a total of 13 years.

Three sources were used to compile the data set. First, the employment, income and population data for each MSA were collected from the Woods and Poole (2008) MSA Profile on CD-ROM. Employment is measured in thousands of jobs. Income is defined as total income per capita and measured in 2004 dollars. Population is measured in thousands of people. The primary source of these historical data is the U.S. Department of Commerce. Second, each MSA is paired with a Land Index (L), a statistic defined by GSS. The GSS data were compiled through a survey sent to 6,896 city managers in 2006 . The survey measured both subjective and objective qualities of a community's approach to growth, zoning restrictions, density 
requirements, and the length of time to get new projects approved. A more detailed description of the index and its construction can be found in GSS. A total of 2,649 municipalities responded, representing communities within defined MSAs and also from rural areas. Finally, the housing price data came from the OFHEO reported by the Federal Housing Finance Authority. The OFHEO includes both sale price data and appraisal data for all MSAs in the US and is a weighted, repeat-sales index. Only single-family houses whose mortgages have been purchased or securitized by Freddie Mac or Fannie Mae since 1975 are included. It is important to note that Freddie and Fannie did not purchase or securitize loans larger than $\$ 729,750$, limiting the OFHEO's ability to describe high-end home prices. The OFHEO is calculated quarterly and is not adjusted for the seasonal housing market. For this reason, the data set contains the year's average of the OFHEO.

\section{References}

Carruthers, J., \& Gudmunder, Ü. (2007). Does "Smart growth" matter to public finance?, U.S. Department of Housing and Urban Development, Working Paper \#REP 06-02.

Ellickson, R. (1997). Suburban growth controls: an economic and legal analysis. Yale Law Journal, 86(3), $385-511$.

Fischel, W. (1985). The economics of zoning laws, Baltimore: Johns Hopkins University Press.

Fischel, W. (2004). An economic history of zoning and a cure for its exclusionary effects. Urban Studies, $40(1), 328-333$.

Glaeser, E., \& Gottlieb, J. (2009). The wealth of cities, agglomeration economies and spatial equilibrium in the United States. Journal of Economic Literature, XLVII, 4, 993-1028.

Glaeser, E., \& Ward, B. (2009). The causes and consequences of land use regulation: evidence from greater Boston. Journal of Urban Economics, 65(3), 265-278.

Glaeser, E., Gyourko, J., \& Saks, R. (2005). Why have housing prices gone up? The American Economic Review, 9(52), 329-333.

Glaeser, E., Gyourko, J., \& Saiz, A. (2008). Housing supply and housing bubbles. Journal of Urban Economics, 64(2), 198-217.

Gyourko, J., Saiz, J., \& Summers, A. (2008). A new measure of the local regulatory environment for housing markets. Urban Studies, 45(4), 693-729.

Hamilton, B. (1975). Zoning and the exercise of monopoly power. Journal of Urban Economics, 5(1), $116-130$.

Ihlanfeldt, K. (2007). The effect of land use regulation on housing and land prices. Journal of Urban Economics, 61(3), 420-435.

Mills, E. (2007). The attrition of urban real-property rights. The Independent Review, XII, 2, 199-211.

Mills, E. (2009). Urban land-use controls and the subprime mortgage crisis. The Independent Review, XIII, 4, 559-565.

Mills, E., \& Sende Lubuele, L. (1995). Projecting growth of metropolitan areas. Journal of Urban Economics, 37(3), 344-360.

Nelson, A. (1999). Comparing states with and without growth management: analysis based on indicators with policy implications. Land Use Policy, 16, 21-27.

Quigley, J. and Raphael, S. (2005). Regulation and the high cost of housing in California, American Economic Review, 2, 232-328

Saiz, A. (2010). The geographic determinants of housing supply, Quarterly Journal of Economics, 125(3), 1253-1296.

Schwieterman, J., \& Caspell, D. (2006). A history of zoning in Chicago. Chicago: Lake Claremont.

Wallace, N. (1988). The market effects of zoning undeveloped land: does zoning follow the market? Journal of Urban Economics, 23, 307-326.

Woods and Poole (2008). MSA Profile, CD-Rom. 